\title{
Analysis of maquis and garrigue communities on the island of cyprus and comparison with calabrian pine communities in terms of ecological characteristics
}

\section{Authors Info \\ S. ILSEVEN \\ Department of Geography, Ataturk Education Faculty, Near East University, Nicosia, Mersin 10,Turkey}

*Corresponding Author Email : silseven66@hotmail.com

Key words

Cyprus island,

Ecological characteristics,

Maquis and Garrigue communities,

Pinus brutia

Publication Info

Paper received :18.08.2016

Revised received : 20.06.2017

Accepted : 28.06.2017

\begin{abstract}
Aim : The aim of this study was to identify the types of Maquis and Garrigues, their features, spread areas and growing conditions, and to compare the ecological features of the Maquis and Garrigue and Calabrian pines (Pinus brutia Ten.) in Cyprus.

Methodology : The plant species, which were collected from different steps of heights and different locations, were identified with the help of herbarium specimens. Additionally, maps were used in order to show the groups, structures characteristically and composition in detail. In order to show the changes in plant layers according to height; north-south, north-west, south east directions, plant and soil bedrock sections where identified and cross-sections were drawn.
\end{abstract}

Results : Calabrian pines, showed an unquestionable dominance over other forest species, but not over Maquis and Garrigue vegetation. Maquis species are able to sprout again after forest fires due to their deep root systems which were not affected by fire. Therefore, following the fires or heavy damages, they spread and even closed in a way that the seeds spilled from the thinning Calabrian pines got no space to germinate. They increased their dominance without human intervention.

Interpretation : The investigations reveal that maquis and garrigues have a greater physiological capacity and ability to adapt to the climate than Calabrian pines. They also make some changes in their organs to show a greater resistance than Calabrian pines and spread more.

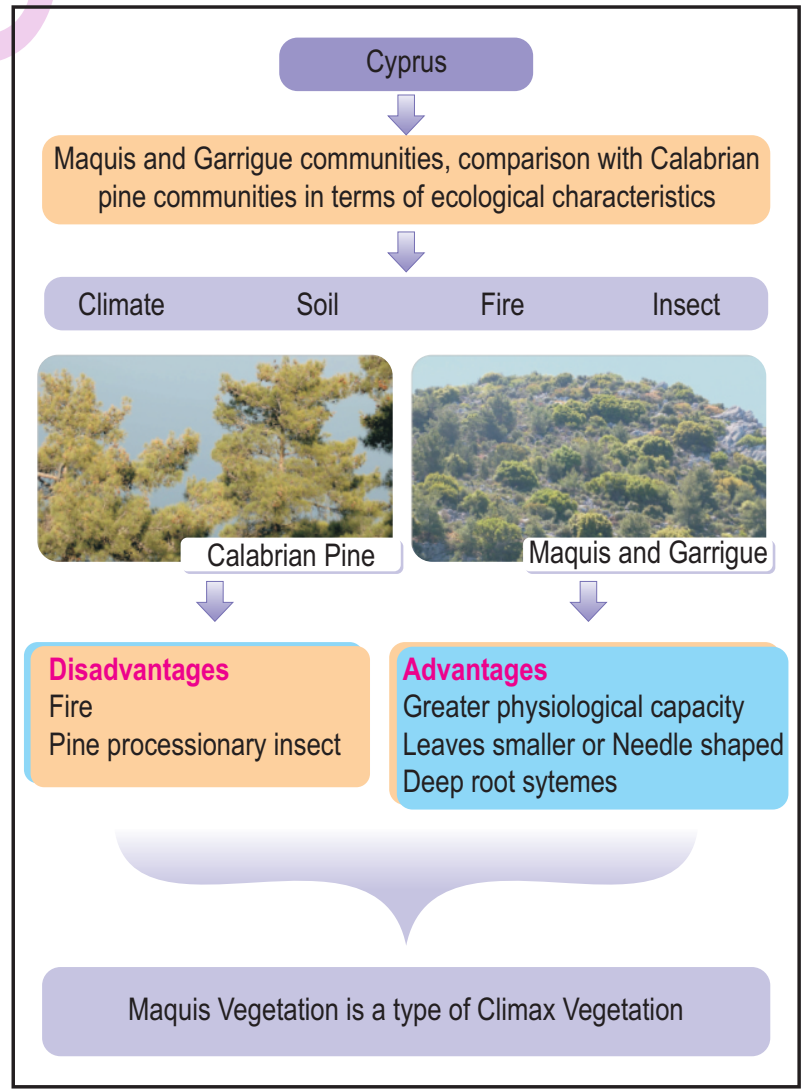




\section{Introduction}

The island of Cyprus is located in the Mediterranean. The characteristics of the Mediterranean climate are that the winters are warm and rainy and summers are hot and dry. In Eastern Mediterranean Basin only vegetation with sclerophyll character develops due to peculiar climate. Plant species comprising maquis and garrigue communities have strongly adapted to this climate. It was observed that the Maquis types constitute vegetation and show a wide spatial distribution. Maquis type vegetation is a secondary in the fields of destructed pine and cypress forests.

Calabrian pine (Pinus brutiaTen.) shows an unquestionable dominance over other forest species, but not over maquis and garrigue. Maquis species are able to sprout again after forest fires due to their deep root systems which are not affected by fire. Therefore, following the fires or heavy damages, they spread and even close in a way that the seeds spilled from the thinning Calabrian pines get no space to germinate. Without human intervention, they increase their dominance. The distribution areas of maquis are controlled by the impact of climatic factors more than the bedrock and soil characteristics.

The aim of this study was to compare shrub elements and the ecological features of Calabrian pines (Pinus brutiaTen) in Cyprus. Effect of climate, geomorphology and other physical environmental factors control the occurrence of different plant groups in Cyprus. The first step is to determine and explain ecological conditions, formations and elements, which decide compositions of forests and maquis. Physiognomic and floristic features of plants and environmental impacts on them are also examined. In this area, maquis and garrigue communities are especially important. However, there has not been any research on maquis and garrigue so far in the area. The present study provides information about the types, spread areas and growing conditions of maquis and garrigue species in Cyprus. Main rock types on which these plants grow and spread have been identified. Shrubs and Calabrian pines were compared ecologically by using annual and monthly climatic data.

\section{Materials and Methods}

Cyprus is located between $34^{\circ} 33^{\prime}-35^{\circ} 41^{\prime} \mathrm{N}$ latitudes and $32^{\circ} 17^{\prime}-34^{\circ} 35^{\prime} \mathrm{E}$ longitudes in the temperate climatic zone in the Mediterranean basin. Therefore, four seasons can be experienced in Cyprus. However, due to its proximity as to the Torrid Zone, the winters are much warmer and summers are hotter as compared to the North Mediterranean coasts (Koday, 1998; Ilseven et al., 2016).

$1 / 100.000$ scale topographical maps, $1 / 20,000$ scale forest management maps 1/100,000 vegetation maps of Forestry Department were used in order to identify the certain spread areas of forest and bush formation in the study area.
The plant species collected from different elevations, during field work between 2010 and 2016 were identified. Additionally, the structures and composition of plant groups were studied. In this respect, plant samples collected during field studies were identified near East University and Alevkayası Herbariums. Furthermore, maps were used to show the groups, characteristic structures and composition in detail.

In order to show the changes in plant layers according to height; north-south, north-west, south east directions, soil, bedrock sections where identified and vegetation cross-sections were prepared.

Meikles' "Flora of Cyprus 1", "Flora of Cyprus 2" and Viney's "An Illustrated Flora of North Cyprus Vol.1 and2" were also used to identify the plant species. The environmental factors, that impact on formation of plant groups were examined in terms of their features. Climatic data of north and south Cyprus were analysed, studied and in the end important bio-climatological results were achieved. In order to identify and determine the features of soil 1/100,000 scale lithology maps were used. As a result, the distributionand ecological needs of maquis, garrigue and Calabrian pine groups were determined and their relations with environment were studied.

Ecological characteristics of study area : Topographically Cyprus comprises three main physical regions namely; the Troodos Mountains in the middle, Kyrenia Mountains along the coastline in the North and Mesaoria (İcova) that sweeps from the Gulf of Morphou in the west and Gulf of Famagusta in the east dividing the highlands into two (Dreghorn, 1978).

Cyprus is within the Mediterranean floral zone, covers the regions of Eastern Mediterranean, coastal low-lands of Balkan Peninsula, coastal area of Western Anatolia, Aegean islands, surrounding the Sea of Marmara, coastal areas of South Anatolia, island of Cyprus and coastal areas of Lebanon, Syria and Palestine. The common climatic factors such as temperature, humidity, rain, wind and sunlight play important role in the composition of natural vegetation of the area (Efe, 2010). Cyprus receives less rain than the western Mediterranean countries. As low pressure moves from the Atlatic Ocean towards the East Mediterranean, it loses its effect when it approaches Cyprus (Ilseven et al., 2016). In general, rainfall is higher in the north than south, and increases in parallel elevation with the mountain ranges throughout the region.

In summer, the sub-tropical high pressure (anticyclone) spreads across the area, sunshine is plenty and rains are infrequent. In winter, cyclonic depressions with frontal rainfall are down into the area by the jet stream (Rice, 2003). Cyprus receives most of the rain in January $(96.6 \mathrm{~mm})$ and December $(76.7 \mathrm{~mm})$. The driest months are August $(1.0 \mathrm{~mm})$ and July with $(2.2 \mathrm{~mm})$. It rains on the high slopes of Trodos, which are the only places where the annual rainfall can reach up to $1000 \mathrm{~mm}$. In Northern 
Cyprus; the highest precipitation is on the northside of Kyrenia and Karpasia mountains and is $550 \mathrm{~mm}$ annually (Gonencgiland Cavus, 2006). Guzelyurt in Mesaoria and Dortyol had the lowest rainfall. Humid air masses, which move to Guzelyurt from the Mediterranean Sea do not confront with any obstacle. As a result, this region receives very little rain. CentralMesaoria, Dortyol and surroundings receive $276 \mathrm{~mm}$ of rain andis the driest place inCyprus. Cyprus receives less and less rainfall each year e.g. was $402 \mathrm{~mm}$ between 1941 and 1970 and decreased below 350 mm between 1975 and 2010 .

Apart from the high points of Trodos mountains, the drought period can extend up to 6-7 months. It is possible to grow Calabrian pines (Pinus brutia Ten), cypress (Cupressus sempervirens L.), kermes oak (Quercus cocciferae L.), juniper (Junipers phonicea L.) and other bushy elements which are resistant to drought, heat and require lots of light on Kyrenia mountains and Trodos slopes reaching to maximum $1000 \mathrm{~m}$. Thus, the natural vegetation profuse in parts where there is a good deal of rain (Mountains) while it weakens in the dry parts (Mesaoria) of the island.

Maquis and garrigue plant communities, which adapted to Mediterranean climate, may need various types of soil. Red Mediterranean soil and brown forest soil have optimum features for grooving of these plants. Rendzina soil, alluvial soil, sandy/pebled soil and volcanic soil also occurs in the area. These are all limy and siliceous soil types. Some of these soil types show acidic reactions while some show alkaline reactions (Bastürk and Aladağ, 2009). Terra rosa soils, which are well developed on limestones are seen more often near flat or flat-like areas. In inclined areas, this type of soil occurs in the cracks of limestone. Brown soil is often found underconiferous forests. Such soil is brown due to their rich content of organic elements. Forests are located mostly on inclined slopes. Therefore, brown forest soil does not have thick layers due to high inclination. Brown soils are also common under the Calabrian pine forests in the northern slopes of Trodos mountains.

Some of the maquis and garrigue species are spread into the river beds and flat areas where soil is fertile and thick. There, their growth is good and they resemble high shrubs-tree that is called high-maquis. High maquis include tall shrubs and small trees of varying heights and prefer shady slopes and sheltered locations (Dallman,1998). Dominant plants are kermes oak (Quercus coccifera L.), carob tree (Ceratonia siliqua L.), olive tree (Olea europeaL.), eastern strawberry tree (Arbutus andrachne L.) in the maquis formation. Maquis elements are widespread in valleys and low slopes on Kyrenia mountains and Trodos mountains. However, garrigue elements are rarely seen in Mesaoria and step areas where the amount of average annual precipitation is below $400 \mathrm{~mm}$.

\section{Results and Discussion}

Locational analysis of maquis and garrigue vegetation in Cyprus : Maquis and garrigues form an important component of Mediterranean climate. The maquis community comprises evergreen plants with leathery leaves, with the height of 1-2 $\mathrm{m}$. Shrub elements can sometimes form groups of high bushes and small trees, which are taller than $2 \mathrm{~m}$ (Efe, 1998). Some parts of shrubby areas in Cyprus were once forests before being destroyed by human activity and showed the features of secondary vegetation; but a significant part of shrubs can also show primary formation features and distribution. Winter is warm in Cyprus, so vegetation period continue throughout the year. Maquis species have long roots and can get water from deep soil during dry and hot summers. Due to this fact, in contrast to Calabrian pines, the shiny, hard and feathery surface of the leaves of shrubs protects them from high temperature during summer. As a result, transpiration is reduced and shrubs can resist to hot summers. Mastic bush (Pistacia lentiscus L.), myrtle (Myrtus communis L.) and Kermes oak (Quercuscoccifera L.) are characteristic species of Mediterranean climate whichdo not grow outside the Mediterranean region (Atalay and Efe, 2015; Ozelet al.,2006). Carob (Ceratonia siliqua L.), mastic bush (Pista cialentiscus L.) and myrtle (Myrtus communis L.) cannot be seen even in Mediterranean region over a certain altitude. Typical shrubs can only grow in areas where altitude is up to $700 \mathrm{~m}$. After this altitude shrubs, which need a significant amount of heat do not grow. On the other hand, shrubs such as kermes oak, mastic tree, eastern strawberry tree, styrax and rockrose can be seen widely since they generally do not need hot environments (Dönmez,1985; Efe,2014).

Apart from shrubs there are some plant species, which grow on limestone and limy soils. They generally occupy the drier, hotter regions with less fertile soil. These plants are shorter than shrubs and emerge after shrubs are destroyed. They are called "garrigue"or "frigana". Garrigue species are common in the areas where shrubs were destroyed. They can reach up to $0.5-1 \mathrm{~m}$ in height. They have needles, deep roots and require less humidity to survive. Garrigue species have small, thick and leathery leaves and can resist the hot and dry climate (Atalay, 1983; Efe, 2007). For example, spiny brooms (Calycotome villosa Poir.) drop all their leaves in summer and change colour to minimize transpiration; thereby they do not die in hot summers. Thyme (Thymus capitatus L.), spiny burnet (Sarcopotarium spinosum L.), heath (Erica manipuliflora Salisb.)are the other well-known garrigue elements (Christofides, 2001) occur in the study area. The vegetation on north slopes of Kayalar mountains have been damaged due to the overgrazing and forest fires. The south skirts of Kyrenia mountains, especially the fields between Gecitkale and Iskele are the areas where garrigues are widely seen. In south Cyprus, garrigues grow excessively between Famagusta and Larnaca and also in the south of Mesaoria (Tsintides et al., 2002). 
Garrigue formation occupies hot, dry, rocky and sloped places where soil is thin. These sclerophyll plant groups can more or less be seen all around the Mediterranean basin. Ecological conditions in Cyprus are suitable for these plants to grow (Efe, 2010; Curebal et al., 2015).

Shrub elements in Cyprus consist of golden oak (Quercus alnifolia Poech), eastern strawberry tree (Arbutus andrachne L), strawberry tree (Arbutus unedo L.), carob (Ceratonia siliqua L.), terebinth (Pista ciaterebinthus L), mastic bush (Pista cialentiscus L.), myrtle (Myrtus communis L.), olive (Olea oleaster L.), Kermes oak (Quercus coccifera L.), rockrose (Cistus creticus L.), sage (Salvia fruticosa Mill.), stryax (Styrax officinalis L.), laurel (Laurus nobilis L.) and Persian lilac (Melia azedarach L.).Garrigue and bushes are spiny broom, (Calycotome villosa Poir.), caper bush (Cappariss pinosa L.), spiny burnet (Sarcopotarium spinosum L.), stinking bean trefoil (Anagyris foetida L.), Cyprus broom (Genistas phacelata Spach.), white beam (Sorbus aria L.), hazelnut (Corylus avellana L.), castor oil plant ( Ricinus communis L.), sumach (Rhus coriaria L.), heath (Erica manipuliflora Salisb.), mock privet (Phillyrealati folia L.), chaste tree (Vitex agnuscastus L.), germander (Teucrium creticum L:), rosemary (Rosmarinus officinalis L.), thyme (Thymus capitatus L.), liquorice (Glycyrrhiza glabra L.), buckthorn (RhamnusalaternusL.), azarole (Crataegus azarelus L.), red azarole (Crataegus monogyna Jacq.), sage (Salvia grandiflora L.) and Cyprus sage (Salvia fruticosa Mill).

Locational analysis of Calabrian pines in Cyprus : Forests spread on large area on the northern slopes of Kyrenia mountains. Forests also occur around Lapta Karsıyaka, Tepebası, Akdeniz village, Alevkayası, Kantara localities. The most characteristic elements of these forests are Calabrian pines (Pinus brutia Ten.), cypress (Cupressus sempervirens L.) and Junipers (Juniperus phoeniceaL.). Especially in Lapta region, forests mixed with cypress and Calabrian pines start at the sea level and reach up to the peaks of mountains. Servilitepe's north face is the perfect place for the spread of the cypress trees. Due to suitable climate, cypress trees in this area can grow up to 20-25 m of height. Phoenician junipers form small groups around Akdeniz village in the east of Kantara mountains. There are grey elm (Ulmus canescens Melville) and plane (Platanus orientalis L.) trees on the valleys that are facing the north on Kyrenia mountains. Blunt-leaved maple (Acer obtusi folium Smith) and Aleppo oak (Quercus infectoria L.) are the evidence of humid climate, which once existed in Cyprus. Eucalyptus trees (Eucalyptus camaldulensis Dehnh.) can occasionally be seen in valleys at the centre of the island.

The effects of climate, soil and morphology are important for plants. If one of these factors does not exist, plants cannot reach their optimum growth. Climate elements independently determine the lives of plants (Efe, 2010; Toroglu and Ulker, 2008). Trodos mountains are the most suitable places in terms of climate, soil and morphology. Cedar (Cedrus libani var. brevifolia Hook.f.), Calabrian pine (Pinus brutia Ten.) and black pine (Pinus nigravar. Pallasiana (Lamb.) Holmboe) are seen on Trodos mountains. Kermes oak (Quercuscoccifera L.) and golden oak (Quercus alnifolia Poech) which are maquis elements that do not drop leaves. Species such as allepo oak (Quercus infectoria Oliv.), oriental alder (Alnus orientalis Decne), mediterranean elm (Ulmus canescens Melville.), maple (Acer obtusifolium Smith) and oriental planes (Platanus orintalis L.) drop leaves in winters. There are gallery forests in valleys on the north and northwest slope of Trodos mountains. Theyare formed by tall and large trees such as oriental alder (Alnus orientalis Decne) and Uzbek poplar (Populus usbekistanica L.)(Tsintides et al., 2002).This situation applies to all the valleys on Trodos mountains skirts facing north and northwest. In Karkotis and Diyarizos valley, in addition to the species mentioned above, aspen (Populus tremula L.), common silver birch (Betula pendula Roth.), and Mediterranean elm (Ulmus canescens Melville) are also found.

Calabrian pine is the most common pine species in Cyprus. Pine forests can be seen up to $1050 \mathrm{~m}$ in Kyrenia mountai ans and $1600 \mathrm{~m}$ elevations on Trodos slopes. The trunk diameter of these trees can be up to $1 \mathrm{~m}$ and can grow up to 20-25 m high (Yaltırık, 1993,1997). Calabrian pine is cold and drought resistant and can grow the best on the northern slopes of Kyrenia mountains and north/north-west slopes of Trodos mountains. Calabrian pines also occur in small groups on Karpaz hills, and Mesaoriaaswell as in the vicinity of Akama and Piskobu.

Damaged pine trees become weak and attract harmful insects and secondary pests (Atalay and Efe, 2015). The biggest enemy of Calabrian pines is Thaumetopoe apityocampa Schiff). These moths can be identified from their white cotton-like worm sacs. The insects build their sacs on leaves, which are near the top shoots. Once this harmful insect forms its sac after changing shoots for 3 times, it stays there until it dies. It damages the tree by going in and out of its sac and it never leaves its location (Onaran and Katı, 2010). They are actually a type of butterflies but they are one of the most harmful insects for forests in Cyprus. The trees, which are infected by these insects for 2-3 consecutive years, show decrease in size and growth. Pine processionary insects are seen at the sidelines of forests or on individual trees when insect density is low. When insect density increases, the number of damaged trees and worm sacs on each tree increases. When pine processionary caterpillars stay longer on the tree, they completely destroy the tree.

Apart from Calabrian pine, forest elements in Cyprus are: common cypress (Cupressus sempervirens L.), pyramidal cypress (Cupressus sempervirens pyramidalis L.), Cyprus cedar (Cedrus libani var. brevifolia Hook.), black pine (Pinusnigra var. pallasiana (Lamb) Holmboe), aleppo pine (Pinus halepinsis Mill.), stone pine (Pinus pinea L.), canary pine (Pinus canariensis C.Smith), phoenician juniper (Juniperus phoenicea L.), prickly 
juniper (Juniperus oxycedrus L.), stinking juniper (Juniperus foetidissima Willd), Grecian juniper (Juniperus excels M.Bieb), Ironwood=whistling pine (Casuarina equisetifolia L.), sandarac tree (Tetraclinis articulata Vahl.), giant sequoia (Sequoidendron giganteum Lindl.), coast redwood (Sequoia sempervirens L.), cilician fir (Abies cilicica Ant. and Kotschy carriere), Grecian fir (Abies cephalonica L.), Uzbek poplar (Populus usbekistanica L.), aspen (Populus tremula L.), common silver birch (Betula pendula Roth), mediterranean elm (Ulmus canescens Melville), oriental plane (Platanus orientalis L.) blunt-leaved maple (Acer optiifollium Smith), allepo oak (Quercus infectoria Oliv.), oriental elm (Alnus orientalis Decne), tamarix (Tamarix artculata Vahl), parkinsonia (Parkinsonia aculeata L.) and tree of haven (Ailanthus altissima (Mill.) Swingle)(Viney,1994 and 1996).

Comparison of Calabrian pine, maquis and garrigue communities in terms of ecological characteristics: Cyprus as a part of its natural surrounding is unique in location, topography, different altitude and slope groups, geology, hydrological structure and rich vegetation which is a result of its climate and various ecosystems are all important as a whole (llseven, 2004). The main distribution areas of maquis and garrigue are the coastal areas where the Mediterranean climate prevails. Mediterranean bush communities, which begin from shores, continue upto 400-500 m or sometimes even 600-700 m in the Mediterranean climate zone. After these levels, Calabrianpines and cypress, which are the dominant types of the Mediterranean forests, spread.

Calabrian pines and cypress, which show undisputable dominance in Mediterranean forest elements and shrubs, also help to identify the effect zone of the Mediterranean climate. Some shrubs form understory flora of Calabrian pine trees. Shrubs are significantly common in places where Calabrian pines were destroyed. This research has shown that kermes oak (Quercus coccifera L.), laurel (Laurus nobilis L.) and styrax (Styrax oficinalis $L$.) which are maquis elements can grow up to 6$10 \mathrm{~m}$ in height and have trunks with $25-40 \mathrm{~cm}$ diameter in the valleys of Trodos and Kyrenia mountains on the high northern slopes of Servilitepe. Eastern strawberry trees (Arbutus andrachne L.) have 30-35 diameter trunks. When they are destroyed by fires they can grow again. This is the proof of there can be a primary vegetation there (Ilseven, 2014). Eastern strawberry in the south of Alevkayası was measured to have a girth of $3.5 \mathrm{~m}$. Kermes oak which is in the garden of a little church in the east of Servili mount was measured to have a height $10 \mathrm{~m}$. The are several oaks with a girth $2.5 \mathrm{~m}$ and height $20 \mathrm{~m}$ near Karaman.

In Mediterranean climate zone it rains only during winter months and there is a high level of drought in summer months with little rainfall. Summer is more basic in terms of air movements as compared with winter. Basra low pressure zone in the south is effective during summer in Cyprus. It is dry and hot during June and August. There is almost no rain in Cyprus and the Mediterranean basin during summer (Ilseven et al., 2016). The main characteristics of the Mediterranean climate in Cyprus can be seen until $700-800 \mathrm{~m}$ from the shores. The annual average temperature is above $12^{\circ} \mathrm{C}$. Vegetation period continues for 365 days without any interruption. Maquis plants show a great adaptation to these environments. Minimum temperature is -13.6 ${ }^{\circ} \mathrm{C}$ in Trodos and maximum $45^{\circ} \mathrm{C}$ in Mesaoria in July. The annual rainfall in the Mediterraneanfloral region is above $400 \mathrm{~mm}$. The amount of rainfall increases up to $1000 \mathrm{~mm}$ on the slopes of Trodos mountains. Temperature decreases to $5-6^{\circ} \mathrm{C}$ on higher parts of mountains. As a result, the maquis and garrigue species infrequent on the high slopes of Trodos Mountains. Some bush elements that are not seen in the North Range occur on the slopes along with shrub groups. These arewestern strawberry tree (Arbutus unedo L.), golden oak (Quercus alnifolia Poech), hazelnut (Corylus avellana L.) and red hawthorn (Crataegus monogyna Jacq.).

Calabrianpine is the dominant species in the forests in Cyprus.Rockrose (Cistus creticus L.) forms the flora of understory of Calabrian pineforest. Apart from these trees myrtle (Myrtus communis L.), eastern strawberry tree (Arbutus andrachne L.), spiny burnet (Sarcopotorium spinosum (L.)Spach.) and common polypodium (Polypodyum vulgare L.) are also common in some areas.

Fires may be the most distinguishing factor for the Calabrian pines and Maquis that are examined in this research.Calabrian pine is one of the most sensitive trees to fires. Their needles catch fire easily and pinecones explode and lead to uncontrollable forest fires. Maquis and garrigue species can produce shoots after fire because of their strong and long roots. For that reason, they spread extensively and become dense afterdestruction of Calabrian pines. They do not even allow the seeds of Calabrian pine to germinate (Meikle, 1985).

If there is no human interference, maquis can grow easily, but Calabrian pine cannot grow again. Maquis has become more common than Calabrian pines after the fires in 1974 and 1995. Maquis and garrigue can be seen all around Cyprus and the Mediterranean flora zone. The speed of their sprout is much faster than that of Calabrian pines. Their seeds are so light that wind and flood can help them spread fast. Kermes oak shows similarity with Calabrianpines when they spread into areas. This study proved that kermes oaks went out of the spread area of Calabrian pines from time to time. The wild olive trees are common on thelower slopes of Trodos mountains and Kyrenia mountains.

Maquis vegetation is a type of climax vegetation, which showed adaptation and resistance to hot and dry summers in Cyprus. Calabrian pine is the most common species in the study area. This plant has become adapted to the Mediterranean region and can survive in areas where soil and climate conditions were 
not changed. If these conditions continue, Calabrian pine is quite competitive with other tree species. However, due to human activities and fires, Calabrian pines are damaged and maquis elements spread and form secondary type vegetation in the study area (Atalay, 2014). This study reveals that maquis and garrigues have a greater physiological capacity and ability to adapt to the climate than Calabrian pines. They are more resistant to drought and fire than Calabrian pines. In summer leaves of garrigue species become smaller or needle-shaped. During this phase, the green trunks make photosynthesis (Atalay, 1983). Bush types such as thyme (Thymus capitatus L.), rest harrow (Ononis spinosa L.), kidney Vetch (Anthyllis vulneraria L.) have protective hairs on their branches to survive in drought. The epidermis of carob, mastic bush, terebinth, mock privet, Mediterranean buckthorn, myrtle and Aleppo oak are species resistant to drought in the study area.

\section{References}

Atalay, I.:: Vegetation Geography of Turkey, Ege University Press, Izmir (1983).

Atalay, İ. and R. Efe: Biogeography of Turkey Meta Publishing, Izmir (2015).

Atalay, I., R. Efe and M. Ozturk: Ecology and classification of forests in Turkey. Elsevier-Procedia Social and Behavioral Science, 120, pp. 788-805 (2014).

Baştürk, K. and C.Aladağ: Analyse of distribution areas in Turkey and ecologic characteristics of Maquis and Garrigues communities, Selçuk University. Social Science J., 22, 68-72 (2009)

Blondel, J., J. Aronson, J. Bodiou and G. Boeur: The Mediterranean Region, Oxford University Press, Great Britain (2010).

Cristofides, Y.: The Orchids of Cyprus. Printed in Cyprus by Lithostar (2001).

Curebal, I., R. Efe, A. Soykan and S. Sönmez: Impact of anthropogenic factors on land degradation during Anthropocene in Turkey. J. Environ. Biol., 36, 51-58 (2015).

Dallman, P.R.: Plant life in the world's mediterranean climates, University of California Press, California (1998).

Dönmez, Y.: Plant Geography, Istanbul University, Publ. No: 3319, Guryay Publishing, Istanbul (1985).

Dreghorn, W.: Land forms in the Girne Range, MTA Press, Ankara (1978).
Efe, R.: Natural environment properties of Ermenek River Basin (Taurus Mountains, Southern Turkey), İstanbul. p. 210 (1998).

Efe, R. and M. Greenwood: Vegetation zonation patterns on the Göksu Delta (Southern Turkey). J. App. Scie., 7, 2277-2284 (2007).

Efe, R.: Ecological properties of vegetation formations on karst terrains in the central taurus mountains (Southern Turkey) Procedia- Social and Behavioral Sciences, Volume 120, Pages 673-679. http://dx.doi.org/10.1016/j.sbspro.2014.02.148(2014).

Gönençgil, B. and E. Çavuş: Climate of North Cyprus. Elci Publishing, Istanbul (2006)

Illseven, S.: Wild and Planted Trees in North Cyprus. Kozansoy Press, Famagusta, North Cyprus (2004).

Illseven, S., G. Hıdırer and A. Tümer: Geography of Cyprus. Ministry of Education Publishing, Nicosia, North Cyprus (2016).

Koday, Z.: Natural vegetation and forestry in northern cyprus, Atatürk University. J. Geogr., 33, 261-282, (1998).

Meikle, R.D.: Flora of Cyprus. Bentham and Moxon Trust Press, London (1985).

North Cyprus Meteorology Journal Bulletin (2013).

Onaran, M.A. and M. Katı: Pine Processionary Insect (Thaumetopoeo pityocampa Shiff). Balıkesir University Inst. Science, 12, 21-27 (2010)

Özel, N., N. Altun, H.A. Öner, A.N. Akbin, N. Altun and H.H. Önerm: Relationship between plant communities and growth environments in ege region. Ministry of Forestry and Environment, Ege Technical Research Directory, Technical Journal No:31 İzmir (2006).

Rice, W.F.: The fabric of geography. Longman Group LTd, Printed in Hong Kong C\& C Joint Co. South Cyprus Meteorology Journal Bulletin (2013).

Toroglu, E. and U.E.Unaldl: Natural Vegetation in Aladaglar and communities in terms of ecological characteristics, Firat University. J. Social Sci., 18, 23-48 (2008).

Tsintides, C., N. H. Takis, G.Christodoulu and S. Charalambos: Trees and Shrubs in Cyprus, Foundation, A. G. Leventis Cyprus Forest Association, Publishing, Nicosia (2002).

Viney D. E.: An Illustrated Flora of North Cyprus. Volume I, Koenigstein,Press, Germany (1994).

Viney D.E.: An Illustrated Flora of North Cyprus. Volume II, A.R.G.Gantner Press, Vaduz Liechtenstein (1996).

Yaltırık, F.: Dendrology, Book I, Gymnosperm. Istanbul University, Faculty of Forestry publishing, Istanbul (1993).

Yaltırık, F.: Forest and Parking Trees, Coniferous. Atlas Publishing, Istanbul (1997). 